\title{
REPRODUCIBILITY ANALYSIS OF THE STABILITY AND TREATMENT OF VERTEBRAL METASTATIC LESIONS
}

\author{
ANÁLISE DA REPRODUTIBILIDADE DA ESTABILIDADE E DO TRATAMENTO DE LESÕES \\ METASTÁTICAS VERTEBRAIS
}

\section{ANÁLISIS DE LA REPRODUCTIBILIDAD DE LA ESTABILIDAD Y DEL TRATAMIENTO DE LESIONES METASTÁTICAS VERTEBRALES}

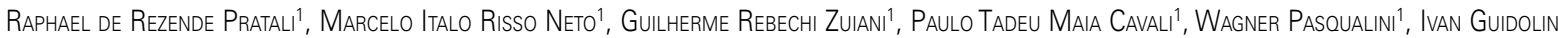

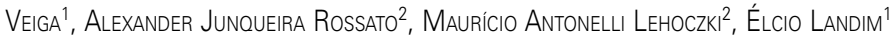

\begin{abstract}
Objectives: To investigate the reproducibility among spine surgeons in defining the treatment of vertebral metastatic lesions, taking into account the mechanical stability of injuries. Methods: Twenty cases of isolated vertebral metastatic lesions were presented to ten experts. Their opinion was then asked about the stability of the lesion, as well as their treatment option. Results: The interobserver Kappa coefficient obtained both for stability analysis as to the decision of the treatment was poor ( 0.334 and 0.248 , respectively). Conclusions: Poor interobserver reproducibility was observed in deciding the treatment of vertebral metastatic lesions when considering the stability of the lesions.
\end{abstract}

Keywords: Spine/surgery; Neoplasm metastasis; Instability indexes; Reproducibility of results.

\section{RESUMO}

Objetivo: Investigar a reprodutibilidade entre cirurgiões de coluna quanto à definição do tratamento de lesões metastáticas vertebrais, levando em consideração a estabilidade mecânica das lesões. Métodos: Vinte casos de lesões metastáticas vertebrais isoladas foram apresentados a dez especialistas. Foi então solicitada sua opinião sobre a estabilidade da lesão e a seguir, sua opção de tratamento. Resultados: O coeficiente Kappa interobservadores obtido tanto para análise da estabilidade quanto para a decisão do tratamento foi ruim (0,334 e 0,248, respectivamente). Conclusões: Foi obsenada reprodutibilidade ruim interobsenvadores na decisão do tratamento de lesões metastáticas vertebrais ao considerar a estabilidade das lesões.

Descritores: Coluna vertebral/cirurgia; Metástase neoplásica; Índices de instabilidade; Reprodutibilidade dos testes.

\section{RESUMEN}

Objetivo: Investigar la reproducibilidad entre cirujanos de la columna vertebral en la definición del tratamiento de las lesiones metastásicas vertebrales, considerando la estabilidad mecánica de esas lesiones. Métodos: Veinte casos de lesiones metastásicas vertebrales aisladas fueron presentados a diez expertos. Luego se les pidió su opinión sobre la estabilidad de la lesión y su opción de tratamiento. Resultados: El coeficiente Kappa entre observadores obtenido tanto para el análisis de la estabilidad y para la decisión de tratamiento fue pobre (0,334 y 0,248 respectivamente). Conclusiones: Se observó mala reproducibilidad entre obsenadores en decidir el tratamiento de lesiones vertebrales metastásicas basada en la estabilidad de esas lesiones.

Descriptores: Columna vertebral/cirugía; Metástasis de la neoplasia, Índices de inestabilidad; Reproducibilidad de resultados.

\section{INTRODUCTION}

Metastatic disease in the spine is a frequent and serious problem, the incidence of which has increased progressively with the evolution of primary cancer detection methods and treatments. ${ }^{1}$ Metastasis is the most common type of skeletal tumor, and the spine is the most common site of bone involvement. ${ }^{2}$

Determining the best treatment method for metastatic lesions in the spine is controversial. In the presence of new neurological damage, or progression of an existing deficit, surgical treatment is the consensus. However, this does not occur in most cases. In general, the treatment decision must take into account several specific factors relative to the patient, the type of primary tumor, and the characteristics of the spinal lesion. For example, determining the level of instability is critical to the decision, as unstable lesions are indicated for surgical treatment. ${ }^{3-5}$ However, there is no consensus as to how instability is determined in metastatic lesions ${ }^{6}$. As a result, the treatment decision based on instability is usually based only on the personal experience of each professional dealing with the patient with these lesions.

The objective of this study is to evaluate the reproducibility of treatment decisions proposed for metastatic vertebral lesions by specialist spine surgeons, based on their impressions of lesion stability.

\section{METHODS}

Twenty cases of patients with isolated metastatic lesions of the spine were organized in PowerPoint ${ }^{\circledR}$ (Microsoft Corp.) files, and presented to ten specialist spine surgeons; nine orthopedists and one neurosurgeon.

Each case presented clinical patient data, such as sex, age, nature of the primary tumor, and information about the aspect of pain. The imaging exams were then presented, including radiography, computed tomography, and magnetic resonance. (Figure 1) The surgeons were then asked to classify each lesion, in terms of its stability, as stable, potentially unstable, or unstable and then, to define their treatment option, based on the stability of the lesion, as conservative, potentially surgical, or surgical. The responses were used to assess interobserver reproducibility among the examiners, with statistical analysis performed by calculating the Fleiss' Kappa coefficients.

1. Department of Orthopedics and Traumatology of the Universidade Estadual de Campinas (Unicamp), Campinas SP, Brazil.

2. Associação de Assistência à Criança Deficiente (AACD), São Paulo, SP, Brazil. 


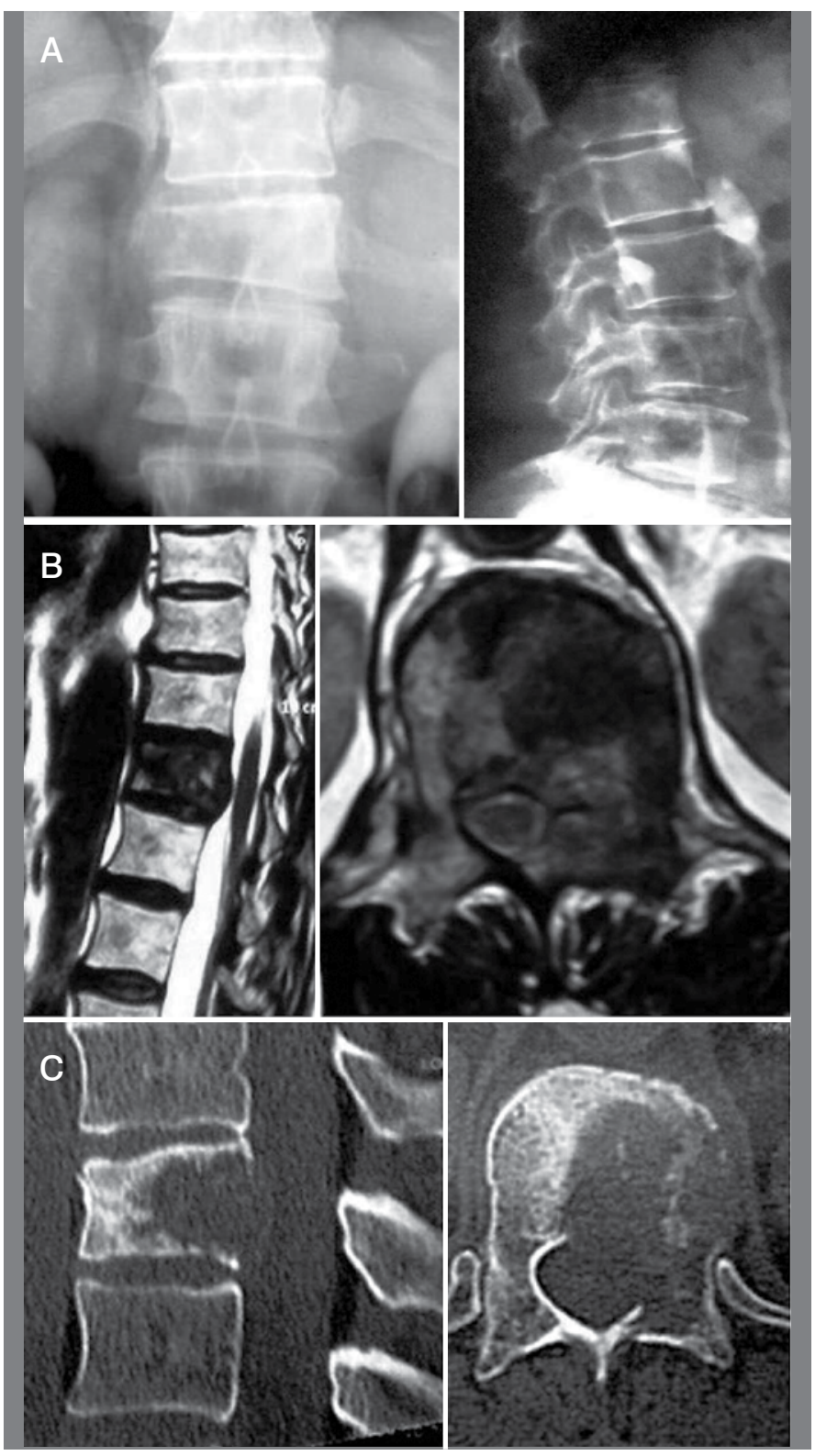

Figure 1. Radiographies (A), Magnetic Resonance (B), and Computed Tomography $(\mathrm{C})$ of one case presented to the examiners.

\section{RESULTS}

Of the ten surgeons who participated in the study, nine were orthopedists and one was a neurosurgeon, all of them working in centers of reference in the treatment of spinal pathologies, and experienced in treating metastatic lesions of the spine. The average years of experience in spinal surgery of the examiners was 17 years, with a minimum of three years and a maximum of 38 years.

The Kappa coefficient values obtained in the analysis of interobserver reproducibility regarding instability and treatment decision were 0.334 and 0.248 , respectively. (Table 1 ) Both numbers indicate poor agreement between the examiners' responses.

Table 1. Kappa values for reproducibility in relation to instability and to a treatment decision.

\begin{tabular}{c|c|c|c}
\hline & KAPPA & Highest Cl (95\%) & Lowest Cl (95\%) \\
\hline Instability & 0,334 & 0,238 & 0,430 \\
\hline Treatment decision & 0,248 & 0,173 & 0,323 \\
\hline
\end{tabular}

\section{DISCUSSION}

Treatment of metastatic lesions of the spine is challenging and the difficulty begins with the choice of the best treatment. The decision to perform surgery depends on specific patient factors, such as overall health, prognosis, and tumor histology. The neurological condition and the stability of the spinal lesion also factor in the decision regarding treatment. The development of well-defined treatment plans is fundamental in guiding the decision on treatment of metastatic lesions in the spine. Many classification systems have been developed and described, aimed at guiding this treatment.

In 1986, Harrington ${ }^{3}$ published a classification for metastatic diseases of the spine. It was divided into five categories, according to the extent of neurological impairment or bone destruction. Based on this classification, the author attempted to organize the treatment of the lesions into oncological or surgical approaches.

In 1989 and 1990, Tokuhashi et a/7,8 proposed a preoperative score to define the prognosis of survival of patients with spinal metastases and to choose treatment options. This score was based on six parameters, including general conditions (performance status), extra-spinal bone metastases, number of spinal metastases, metastases in the internal organs, primary tumor histology, and neurological condition. Based on these parameters, a score was calculated indicating one of the treatment modalities, which included conservative treatment, palliative surgery, or excisional surgery.

Following the description of the most aggressive approach, known as total en bloc spondylectomy ${ }^{9}$, other oncological concepts began to be considered, as they achieved successful local control in spinal lesions. In 2001, Tomita et $\mathrm{a}^{10}$ proposed a new scoring system based on prognoses for metastatic diseases of the spine, proposing a scheme for treating these lesions. Three parameters were considered, including histology of the primary tumor, visceral metastases, and bone metastases. Each of these parameters received points towards a prognostic score divided into four groups with specific surgical strategies: basic support, palliative surgery, intralesional excisional or marginal surgery, and wide margin surgery.

In 2004, Gasbarrini et a/ ${ }^{4}$ described an algorithm for the treatment of spinal metastases. By analyzing the clinical characteristics of the patient, the neurological status, and the characteristics of the primary tumor, such as sensitivity to chemotherapy, radiotherapy, or hormone therapy, the system guides the user towards either palliative treatment, decompression surgery or stabilization, and excisional surgery.

In 2006, Bilsky and Smith ${ }^{5}$ divulged a scheme for guiding decisions around the treatment of spinal metastases based on four basic considerations: neurological, oncological, mechanical instability, and systemic disease. This system is called NOMS, which stands for: neurological $(\mathrm{N})$, taking myelopathy and radicular deficit into consideration but also including the degree of medullary compression in the imaging exam; oncological $(\mathrm{O})$, basically reflecting the sensitivity of the tumor to radiotherapy; mechanical instability (M), according to the level of the lesion; and systemic disease (S), which includes both the extent of the neoplastic disease and the presence of comorbidities. Based on these factors, the authors recommend surgery or radiotherapy treatment for metastases, although they state that chemotherapy or hormone therapy may play a role in certain types of tumors.

Although the concept of mechanical instability is critical to the surgical decision-making process in metastatic spinal lesions, ${ }^{3-5}$ the definition of instability resulting from neoplastic processes is not universally established, due to the fact that instability differs significantly from other types of instability, such as that following traumatic injury. Within the context of metastatic lesions, the concept of instability requires other specific criteria, up until now not widely recognized or discussed. The statistical results of this study show this difficulty, with little agreement around the definition of instability across the 20 cases presented to the examiners familiar with the treatment of metastatic lesions in the spine, based on their personal practical experience (Kappa=0.334). 
Likewise, despite the wide range of available schemes, proposed by different authors, to organize the treatment decision in metastatic lesions in the spine, the statistical results of this study show a significant lack of agreement regarding treatment decision based on stability, among the examiners (Kappa $=0.248$ ).

A group of spinal oncology specialists recently published a classification system aimed at guiding the identification of spinal instability caused by neoplastic disease (SINS).${ }^{11}$ Based on a process of evidence-based medicine, taking into account the best information available in the literature and the opinion of specialists, they developed a scoring system with six parameters: site of the lesion, pain, radiographic characteristics of the bone lesion, radiographic spinal alignment, collapse of the vertebral body, and involvement of posterior vertebral elements. By assigning a score to each parameter, spinal stability can be classified into three categories: from 0 to 6 points - "stability"; from 7 to 12 points - "undetermined stability (imminent)"; and from 13 to 18 points - "instability". The authors recommend that patients with a score from seven to 18 be referred to a spine surgeon for specialized evaluation. This new scheme offers the possibility of a more homogeneous interpretation of instability in neoplastic lesions. Despite the SINS scheme having shown almost perfect reproducibility among the specialists responsible for its development, ${ }^{12}$ a more universal dissemination and an assessment of agreement between other specialists is required.

\section{CONCLUSION}

We observed a poor level of agreement in determining treatment based on the stability of metastatic lesions of the spine. These data confirm the difficulty and controversy in defining the instability of metastatic spinal lesions, and consequently, in the treatment decision-making. These data reinforce the need to adopt a universally recognized and reproducible system for the determination of instability and for the decision-making on treatment in metastatic disease of the spine.

All authors declare no potential conflict of interest concerning this article.

\section{REFERÊNCIAS}

1. American Cancer Society. Cancer Facts and Figures. Atlanta: American Cancer Society; 2007.

2. Newman CB, Keshavarzi S, Aryan HE. En bloc sacrectomy and reconstruction technique modification for pelvic fixation. Surg Neurol. 2009;72(6):752-6.

3. Harrington KD. Current concepts review: metastatic disease of the spine. J Bone Joint Surg Am. 1986;68(7):1110-5.

4. Gasbarrini A, Cappuccio M, Mirabile L, Bandiera S, Terzi S, Barbanti Bròdano G, et al. Spinal metastases: treatment evaluation algorithm. Eur Rev Med Pharmacol Sci. 2004;8(6):265-74.

5. Bilsky M, Smith M. Surgical approach to epidural spinal cord compression. Hematol Oncol Clin North Am. 2006:20(6):1307-17.

6. Weber MH, Burch S, Buckley J, Schmidt MH, Fehlings MG, Vrionis FD, et al. Instability and impending instability of the thoracolumbar spine in patients with spinal metastases: a systematic review. Int J Oncol. 2011;38(1):5-12.

7. TokuhashiY, Kawano H, Ohsaka S, Matsuzaki H, Toriyama S. A scoring system for preoperative evaluation of the prognosis of metastatic spine tumor (a preliminary report). Nihon Seikeigeka Gakkai Zasshi. 1989;63(5):482-9.
8. Tokuhashi Y, Matsuzaki H, Toriyama S, Kawano H, Ohsaka S. Scoring system for the preoperative evaluation of metastatic spine tumor prognosis. Spine (Phila Pa 1976). 1990:15(11):1110-3

9. Tomita K, Kawahara N, Baba H, Tsuchiya H, Fujita T, Toribatake Y. Total em bloc spondylectomy. A new surgical technique for primary malignant vertebral tumors. Spine (Phila Pa 1976). 1997;22(3):324-33

10. Tomita K, Kawahara N, Kobayashi T, Yoshida A, Murakami H, Akamaru T. Surgical strategy for spinal metastases. Spine (Phila Pa 1976). 2001;26(3):298-306.

11. Fisher CG, DiPaola CP, Ryken TC, Bilsky MH, Shaffrey $\mathrm{Cl}$, Berven $\mathrm{SH}$, et al. A novel classification system for spinal instability in neoplastic disease: an evidence-based approach and expert consensus from the Spine Oncology Study Group. Spine (Phila Pa 1976). 2010;35(22):E1221-9

12. Fourney DR, Frangou EM, Ryken TC, Dipaola $\mathrm{CP}$, Shaffrey $\mathrm{Cl}$, Berven $\mathrm{SH}$, et al. Spinal instability neoplastic score: an analysis of reliability and validity from the spine oncology study group. J Clin Oncol. 2011;29(22):3072-7. 